\title{
Performance of Loan Repayment in Co-operative Bank at Raipur District of Chhattisgarh, India
}

\author{
M.K. Patel ${ }^{{ }^{*}}$, C.R. Patel ${ }^{2}$ and J.R. Patel ${ }^{3}$ \\ ${ }^{1}$ Department of Agriculture, Raigarh (C.G.), India \\ ${ }^{2}$ K.V.K. Raigarh, I.G.K.V., Raipur (C.G.), India \\ ${ }^{3}$ T.C.B. CARS, Bilaspur, I.G.K.V., Raipur (C.G.), India \\ *Corresponding author
}

\section{A B S T R A C T}

Keywords

Correlation, repayment and Cooperative Bank.

Article Info

Accepted:

04 July 2017

Available Online:

10 September 2017
The present investigation was carried out during 2005-06 in four randomly selected cooperative branches of District Central Cooperative Bank (DCCB) of Raipur district. Majority of respondents were regular in repayment of their loan. Correlation analysis between independent and dependent variables also reveals that socio-economic status and extension contact shows positively and highly significant and remaining variables exhibited non-significant relationship with loan repayment performance of respondents. Regarding the major constraints faced by them in loan repayment were low outcome of produce, non-reasonable price of agricultural produce, crop failure due to natural calamities etc.

\section{Introduction}

Agricultural development is an integral part of our country. It involves constant changes in strategy, structure and procedures to achieve a higher level of development. The contribution made to our national growth comprises of several sectors. By and large, agriculture is being the backbone of the Indian economy will continue to remain a single sector contributing to the general prosperity of the nation. The present trend of agriculture is commercialized, which would require more investment. The Indian farmers in general and Chhattisgarh farmers is particulars have small and little resources for which external credit are required for their operation.
In Chhattisgarh, most of the farmers approach to the District Central Cooperative Bank (DCCB) as and when they need credit. The DCCB is sponsored by the State Government and disburses loans to the farming community. The proper utilization and repayment performance of the borrowers help in mobilization of the bank loan for better circulation of money among the larger members. Thus, it becomes important to study the repayment performance of the farmers who had taken loan from the District Central Cooperative Bank. With this background an effort has been made and an investigation is carried out entitled "A study on cooperative 
bank loan repayment performance of the farmers in Raipur district" with the following objectives:

To determine the relationship between independent and dependent variables.

To find out constraints faced by the respondents and suggestions to overcome them.

\section{Materials and Methods}

The study was conducted in randomly selected co-operative bank branches namely Aarang, Abhanpur, Dharsiwa and Mandir Hasaud under District Central Co-operative Bank, Raipur. A random sample of 20 borrowers obtaining loan during the year 2003-04 from each of the four cooperative branches were selected, thus a total number of 80 borrowers were considered as respondents for this study.

The coefficient of correlation was used to find out the relationship between independent variable (viz. age, annual income, socioeconomic status, and number of earners in the family, timely availability, utilization of loan, purpose of loan, type of loan, extension contact and source of information) with dependent variable (repayment performance of the respondents). It was calculated by using following formula suggested by Cochran (1967).

$$
\mathrm{r}=\sqrt{\frac{\sum x y-N(\bar{x} \cdot \bar{y})}{\left(\sum x^{2}-N \overline{x^{2}}\right)\left(\sum y^{2}-N \overline{y^{2}}\right)}}
$$

Where,

$r=$ Coefficient of correlation

$\mathrm{x}=$ Score of independent variable

$\mathrm{y}=$ Score of dependent variable

$\mathrm{N}=$ Number of observation

\section{Results and Discussion}

\section{Relationship between independent variables and repayment performance}

The correlation was computed to determine the relationship between repayment performance of the respondents and independent variables viz. age, annual income, socio-economic status, and number of earners in the family, timely availability, utilization of loan, purpose of loan, type of loan, extension contact and source of information. The results are presented in table 1 .

A perusal of table 1 indicates that socio-economic status and extension contacts of respondents had positive and significant relationship (at 0.01 level of probability) with the repayment performance of respondents $(\mathrm{r}=0.283)$.

The findings of this study are in line with the findings of Rambabu et al., (1991) and Lal (1999) who observed that socio-economic status had positive and significant relationship with the repayment behaviour of borrowers. Deshpande and Nandapurkar (1999) reported a positive and significant relationship between the land holding and repayment performance. Since socio-economic status included several important traits, Viz. education, landholding, occupation, social participation, farm power and material possession etc.

It was likely to influence the repayment behaviour on positive side. Therefore, respondents who are having higher education, more farm power, land holdings and material possession and higher personal contacts in social system, they would be better repayment performance. Yanger (2003) also found that socio-economic status had positive and significant relationship with loan repayment performance and age, timely availability, annual income and earner's percentage were 
non-significant. The study further reveals that age $(r=0.041)$, annual Income $(r=0.093)$, number of earners in the family $(\mathrm{r}=0.009)$, type of loan $(r=-0.645)$, purpose of loan $(r=-$
0.197), utilisation of loan ( $\mathrm{r}=0.101)$, timely availability of loan $(\mathrm{r}=0.091)$ and source of information ( $\mathrm{r}=-0.019)$ are non-significant.

Fig. 1

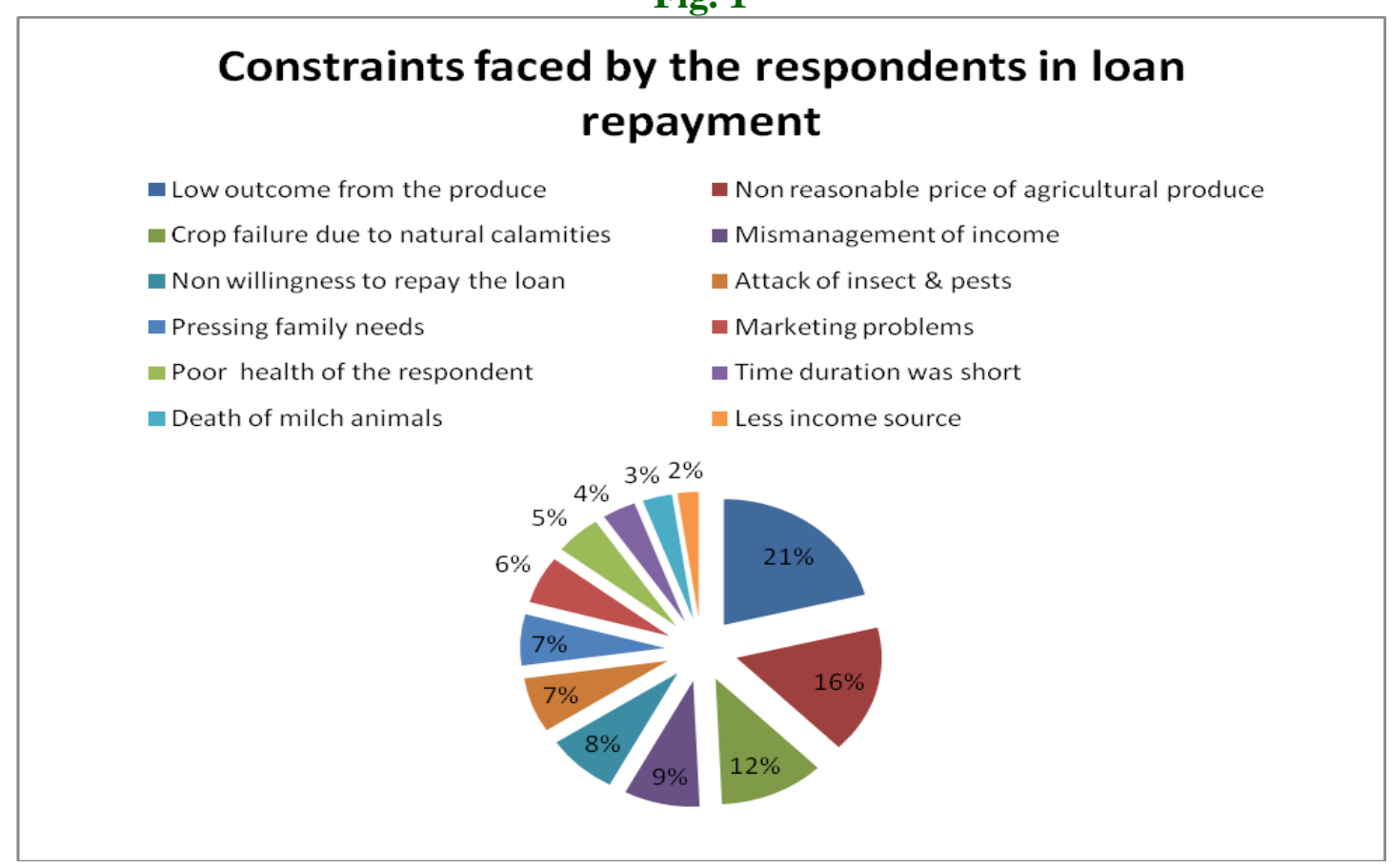

Table.1 Correlation analysis of independent variables with Loan repayment performance of the respondents

\begin{tabular}{|l|l|c|}
\hline S. No. & Independent variables & Correlation coefficient \\
\hline 1. & Age & $0.041 \mathrm{NS}$ \\
\hline 2. & Annual income & $0.093 \mathrm{NS}$ \\
\hline 3. & socio-economic status & $0.317^{* *}$ \\
\hline 4. & Number of earners in the family & $0.009 \mathrm{NS}$ \\
\hline 5. & Type of loan & $-0.645 \mathrm{NS}$ \\
\hline 6. & Purpose of loan & $-0.197 \mathrm{NS}$ \\
\hline 7. & Utilization of loan & $0.101 \mathrm{NS}$ \\
\hline 8. & Timely availability of loan & $0.091 \mathrm{NS}$ \\
\hline 9. & Source of information & $-0.019 \mathrm{NS}$ \\
\hline 10. & Extension contact & $0.537^{* *}$ \\
\hline
\end{tabular}

** Significant at 0.01 level of probability, NS = Non-Significant 
Table. 2 Constraints faced by the respondents in loan repayment

\begin{tabular}{|c|l|c|c|}
\hline \multicolumn{1}{|c}{ Reason } & Frequency* & Per cent \\
\hline S. No. & & 45 & 83.33 \\
\hline 1. & Low outcome from the produce & 35 & 64.81 \\
\hline 2. & Non reasonable price of agricultural produce & 25 & 46.29 \\
\hline 3. & Crop failure due to natural calamities & 18 & 33.33 \\
\hline 4. & Mismanagement of income & 17 & 31.48 \\
\hline 5. & Non willingness to repay the loan & 15 & 27.77 \\
\hline 6. & Attack of insect \& pests & 14 & 25.92 \\
\hline 7. & Pressing family needs & 13 & 24.07 \\
\hline 8. & Marketing problems & 11 & 20.37 \\
\hline 9. & Poor health of the respondent & 8 & 14.82 \\
\hline 10. & Time duration was short & 7 & 12.96 \\
\hline 11. & Death of milch animals & 5 & 9.26 \\
\hline 12. & Less income source & & \\
\hline
\end{tabular}

*Frequency based on multiple responses

Constraints faced by the respondents in loan repayment

The data were collected to find out the constraints faced by the respondents which affect the repayment of their loan. It was interesting to observe that those who were paying their loan regularly $(32.50 \%)$ did not face any problem in repayment; remaining $(67.50 \%)$ respondents reported multiple problems in repaying their loan as given in table 2 and figure 1.

It can be seen from the table that 83.33 per cent of the respondents said that the major constraints was low outcome from the produce. The second important constraint was non-reasonable price to agricultural produce as pointed out by 64.81 per cent respondents. Next constraints were natural calamities such as crop failure as expressed by 46.29 per cent of the respondents. The table further shows that mismanagement of income due to improper planning (33.33\%), non-willingness to repay the loan $(31.48 \%)$, attack of insect \& pests $(27.77 \%)$, pressing family needs (25.92\%), marketing problems such as regulated marketing facilities are not available in the area $(24.07 \%)$, poor health of the respondents $(20.37 \%)$, repayment period is short (14.82\%), death of milch animals $(12.96 \%)$ and less income sources $(9.26 \%)$ constraints were reported by the respondents.

Based on the findings of this study it can be concluded that the respondents, who had higher scores on socio-economic status and timely availability of loan, were repaying their loan regularly.

It can be concluded that the constraints which are hampered to the repayment performance viz. low outcome from the produce, nonreasonable price of agricultural produce, crop failure due to natural calamities, mismanagement of income, pressing family needs, marketing problems, and time duration was short.

Major suggestions given by the respondents to improve their loan repayment performance viz., the rate of interest on loan should be reduced, duration and number of installment should be increased, timely and adequate loan to be provided, support price for agricultural produce should be increased etc. 


\section{Acknowledgments}

We thank our principal guide for his timely help, giving outstanding ideas and encouragement to finish this research work successfully.

\section{References}

Anonymous, 2006. Raipur district central cooperative bank $89^{\text {th }}$ annual report and statement of accounts for the year ended 31st March 2006. Raipur.

Aynew, B., Suhag, K.S., Hasija, R.C. and Mehta, V.P. 2003. Factors affecting overdues of loans - a case study of Primary Land Development Banks in Haryana. Annals of Agri Bio Research, 8(2): 123-130.

Bhaumik, S.K., and Rahim, Abdur.1999. Interlinked credit transactions in rural West Bengal. Ind. J. Agric. Econ., 54(2): 169-184.

Deshpande, S.D., and Nandapurkar, G.G. 1999. Relation of socio-economic profile with repayment and utilization of bank loan by rural women. J. Maha. Agril. University, 23(2): 151-153.

Lal, Roshan, 1999. Utilization and repayment pattern of beneficiaries under DRDAScheme. Unpublished Ph. D. thesis, CCSHAU, Hisar.

Mahal Dinabandhu, 2002. Management of recovery - a study of Parsik Janata Sahakari Bank Ltd. Ind. Co-opt. Rev., Pp. 213-221.

Mishra, R.K., and Pattanaik, S. 2005. Repayment performance of borrowers with respect to agricultural loans in Khurda Block of Khurda District, Orissa. Ind. Co-opt. Rev., 43(1): 423441.

Pareek, U., and Trivedi, G. 1963. Manual of the socio-economic status scale (rural). Manasayan, 32 Faiz bazaar, Delhi-6.

Reddy, A.S., and Rao, B.V. 1999. Performance of challenges of cooperative credit in the content of sustainable rural development. Ind. Coopt. Rev., 37(2): 79.

Safiullah, A., Mal., Meganathan, N. and Selvam, S. 2000. An analysis of credit flow in animal husbandry sector of Tamil Nadu. Fin. Agri. 32 (1): 23-25.

Singh, V.K., Singh, R.A. and Singh, B.N. 1999. The flexibility of cooperative credit in increasing income and, employment of household in Jaunpur District. (U.P). Ind. Co-opt. Rev., 24(3): 240.

Yadav, D.S., 1999. Performance and prospect of agricultural cooperative credit societies in block Bilhaur district Kanpur- Dehat (U.P). Ind. Co-opt. Rev., 37(2): 74.

\section{How to cite this article:}

Patel, M.K., C.R. Patel and Patel, J.R. 2017. Performance of Loan Repayment in Co-operative Bank at Raipur District of Chhattisgarh. Int.J.Curr.Microbiol.App.Sci. 6(9): 341-345. doi: https://doi.org/10.20546/ijcmas.2017.609.043 